\title{
Determination of Hiesho among Young Japanese Females using Thermographic Technique
}

\author{
Tianyi Wang, ${ }^{*}$ \# Shima OKadA, ${ }^{*}$ Masayuki Endo, ${ }^{* *}$ Masaaki Makikawa, ${ }^{*}$ Yuko Ohno ${ }^{* * *}$
}

\begin{abstract}
Hiesho is the condition of having a cold sensation in one's hands or feet. This is a well-known health problem for young Asian females. However, the definition of Hiesho is still controversial. In this study, we aimed to develop a quantitative and non-invasive approach to determine Hiesho. Sixty-three young females participated in this research. Temperature difference $(\Delta \mathrm{T})$ between the forehead and foot sole was utilized to define Hiesho or non-Hiesho condition, and the result was crosschecked with that of a self-reported questionnaire. Central systolic blood pressure and augmentation index were measured to evaluate subjects' physiological indicators. The results of the questionnaire showed that $49 \%$ of young females ( 31 of 63 people) reported Hiesho. There was a significant difference in $\Delta \mathrm{T}$ between non-Hiesho and Hiesho $\left(1.85^{\circ} \mathrm{C}\right.$ and $5.55^{\circ} \mathrm{C}$, respectively, $p<0.01)$. After cross-checking with the self-reported questionnaire, $\Delta \mathrm{T}$ of $3.64^{\circ} \mathrm{C}$ demonstrated acceptable reliability and accuracy for defining Hiesho. Central systolic blood pressure and augmentation index were not different between Hiesho and non-Hiesho. In conclusion, young females with Hiesho had drastically different temperatures at the forehead and foot sole. The temperature difference between the forehead and foot could be used as a quantitative and objective parameter for defining Hiesho.
\end{abstract}

Keywords: Hiesho, thermographic technique, non-invasive method.

Adv Biomed Eng. 10: pp. 11-17, 2021.

\section{Introduction}

Hiesho, also known as a cold sensation, is frequently observed in Asian females [1-3]. The characteristic symptom of Hiesho is a cold feeling, particularly in the hands and feet, at an environmental temperature at which a healthy person does not feel cold [4]. Hiesho is not only related to several health problems in daily life but is also associated with a higher frequency of chronic disease [4, 5]. In Western medicine, Hiesho is not perceived as a

This study was presented at the Symposium on Biomedical Engineering 2020, September, 2020.

Received on July 16, 2020; revised on October 22, 2020; accepted on December 1, 2020.

*Department of Robotics, Faculty of Science and Engineering, Ritsumeikan University, Shiga, Japan.

** Department of Children and Women's Health, Graduate School of Medicine, Osaka University, Osaka, Japan.

**** Department of Mathematical Health Science, Graduate School of Medicine, Osaka University, Osaka, Japan.

\# 1-1-1 Noji-higashi, Kusatsu, Shiga 525-8577, Japan.

E-mail: t-wang@fc.ritsumei.ac.jp

\section{(c) BY}

Copyright: (02021 The Author(s). This is an open access article distributed under the terms of the Creative Commons BY 4.0 International (Attribution) License (https:// creativecommons.org/licenses/by/4.0/legalcode), which permits the unrestricted distribution, reproduction and use of the article provided the original source and authors are credited. remarkable symptom [6]. However, in Japan, approximately $30 \%$ of the patients used Kampo medicines because of Hiesho [7].

Currently, the diagnosis of Hiesho is still controversial. The most popular method for defining Hiesho is through a questionnaire-based survey called "Terasawa Hiesho Questionnaire" [8-10]. As this questionnaire is in Japanese, applying this method in other countries is difficult. Nakamura [8] reported that there was a significantly higher skin temperature difference in pregnant women with Hiesho. However, young Hiesho patients are still unaware of different skin temperatures.

Cutaneous blood flow is controlled by two types of sympathetic nerve systems: cutaneous vasoconstrictor (CVC) and cutaneous vasodilator (CVD). Increased CVC activity results in constriction of cutaneous blood vessels, while increased activity of CVD results in dilation of skin vessels. CVC does not affect cutaneous blood flow at the forehead, whereas peripheral blood flow is affected by CVC activity [11].

We hypothesized that a difference in forehead and foot plantar temperatures exist in young females with Hiesho. To test this hypothesis, we subjectively defined Hiesho using a questionnaire, performed thermal check using thermographic technique, and investigated the usefulness of the proposed method in determining Hiesho. The result of this study is expected to provide a quantitative and non-invasive approach to determine Hiesho. 


\section{Subjects and Methods}

\subsection{Human Subjects}

Sixty-three female students (age: $21.5 \pm 1.7$ years, height: $157.92 \pm 6.07 \mathrm{~cm}$, weight: $51.45 \pm 6.16 \mathrm{~kg}$, body mass index: $20.60 \pm 2.03 \mathrm{~kg} / \mathrm{m}^{2}$ ) with regular menstrual cycles participated in our experiment. No subject reported a history of health problems including endocrinopathy, cardiovascular disease, gynecological conditions, and connective tissue disease. Subjects were required to abstain from alcohol and caffeine for at least one day and from any food at least $2 \mathrm{~h}$ before the experiment.

Before the experiment, all subjects were informed of the purpose and methods of this study and provided written informed consent. Subjects were free to withdraw from the study at any time. This study was approved by the Ethics Committee of Osaka University Hospital (No. 19162, August 2019).

\subsection{Experimental Environment and Methods}

The experiment was conducted from 31st July to 21st October 2019, from 10 a.m. to 4 p.m. Considering that body temperature fluctuates depending on the phase of the menstrual cycle, the experiment was conducted only during the follicular phase. The local temperature during our experiment was: maximum $30.1 \pm 12.3^{\circ} \mathrm{C}$, minimum $22.8 \pm 4.7^{\circ} \mathrm{C}$, and average $26.9 \pm 4.4^{\circ} \mathrm{C}$ [12]. The indoor temperature was $24.6 \pm 0.6^{\circ} \mathrm{C}$, and humidity was $54.5 \pm$ $12.3 \%$.

Before the experiment, we asked the subject to rest for $20 \mathrm{~min}$ to adapt to the experimental environment. Then, each subject responded to a Hiesho questionnaire. A thermal check that captures temperatures from the forehead and the foot (at dominant foot) was utilized to define Hiesho. Finally, we measured blood pressure, pulse wave and augmentation index to investigate the subject's physiological indicators.

\subsection{Defining Hiesho}

In this research, "Terasawa Hiesho Questionnaire" was used to define Hiesho. This questionnaire contains twenty questions, comprising three main questions, five related questions, and twelve minor questions $[8,10]$. A subject who answers positively to (1) two or more main questions, or (2) one main and two or more related questions, or (3) four or more related questions, is defined to be Hiesho; otherwise, a subject is considered to be nonHiesho.

Figure 1 shows the proposed method for defining Hiesho using a quantitative approach. In this study, an infrared thermometer (CFluke Thermometer Ti450) was utilized to measure skin temperature. This thermal equipment is loaded with MultiSharp Focus ${ }^{\mathrm{TM}}$, which pro-

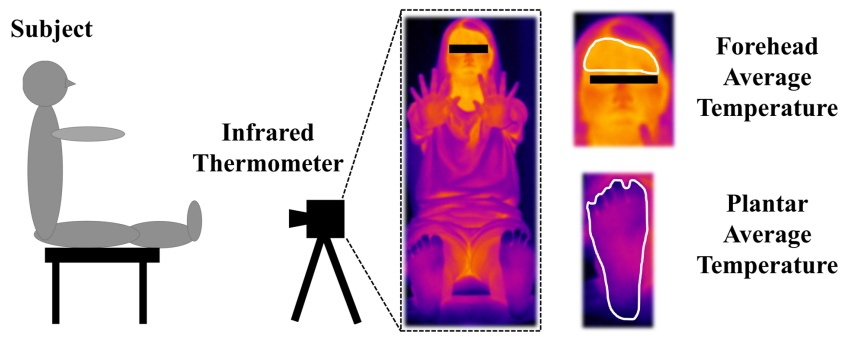

Fig. 1 Image of thermal check.

vides sharp focusing of one image data so that we can acquire high-quality temperature data from the thermal graph. The resolution of this thermometer is $320 \times 240$ pixels, and the noise equivalent temperature difference is $0.03^{\circ} \mathrm{C}[13]$. The thermometer used in this study has been proved to be a highly reliable equipment for collecting temperature data [14].

We asked the subject to sit still on a chair, with their legs stretched on the chair, and ensure that their feet were perpendicular to the ground. Then, we captured a thermal graph image of their entire body. Forehead was defined as the area above the subject's eyebrows and below the hairline. Temperature difference $(\Delta \mathrm{T})$ was calculated as follows:

$$
\Delta \mathrm{T}=T_{\text {forehead }}-T_{\text {plantar }}
$$

where $T_{\text {forehead }}$ represents the average forehead temperature and $T_{\text {plantar }}$ represents the average planar temperature at the dominant foot.

To define the optimal $\Delta \mathrm{T}$, the thermal check result was verified and evaluated in terms of sensitivity and specificity of the questionnaire results, as well as by the area under the receiver operating characteristics (ROC) curve (AUC) analysis of the validation data.

\subsection{Physiological Indicators}

A non-invasive automated blood pressure monitor with augmentation index function (Omron HEM-9000AI; Omron Healthcare, Kyoto, Japan) was used to measure central systolic blood pressure (cSBP), pulse wave and augmentation index (AI) [15]. A scene of measurement is shown in Fig. 2. Systolic blood pressure, diastolic blood pressure, cSBP, pulse pressure, pulse rate, and AI were measured in each subject.

\subsection{Data Analysis}

Average forehead and plantar temperatures were utilized for calculating the temperature difference. The results of the Hiesho questionnaire and $\Delta \mathrm{T}$ for each subject were used to calculate the optimal cut-off value. ROC analyses were conducted using the statistical software MedCalc $₫$ (version 19.2.5). Disease prevalence was calculated as the percentage of Hiesho based on the ques- 


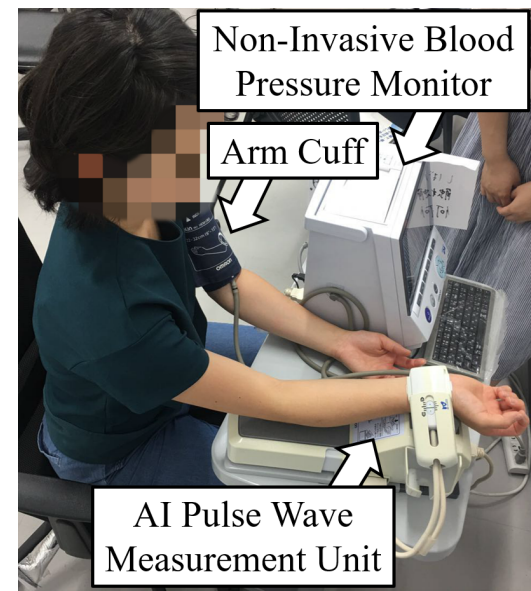

Fig. 2 Measurement of cSBP and AI.

tionnaire results. Student's t-test was used to test the significance of difference between two groups, with the significance level set at $5 \%$. The $t$-test was performed using JASP (version 0.13.1.0, The Netherlands).

\section{Results}

According to the "Terasawa Hiesho Questionnaire", $49.2 \%$ of the subjects ( 31 in 63 people) were defined to have Hiesho. Figure 3(a) shows examples of thermal images of a non-Hiesho and a Hiesho subject. Dark blue indicates low temperature, while dark red represents high temperature. Compared with healthy subjects (nonHiesho group at the left), the colors of the feet and the forehead in the Hiesho group (right image) were totally different, indicating that the temperature at the foot sole was much lower than that at the forehead.

Figure 3(b) shows the results of the ROC curve to define $\Delta \mathrm{T}$ and Hiesho. Optimal $\Delta \mathrm{T}$ was $3.64^{\circ} \mathrm{C}$, with sensitivity $77.4 \%$ and specificity $71.9 \%$. The $\Delta \mathrm{T}$ of $3.64^{\circ} \mathrm{C}$ showed acceptable accuracy for defining Hiesho $($ AUC $=$ 0.753, standard error: $0.061,95 \%$ confidence interval: 0.634 to $0.857, p<0.001$ ).

The subjects' basic information and their thermal check results are summarized in Table 1. There were no significant differences in height, weight, and BMI between the two groups $(p>0.05)$. There was a difference in age between Hiesho and non-Hiesho groups (22.0 \pm 1.5 versus $21.1 \pm 1.8$ years, $p<0.05$ ), Cohen's $d$ suggested that this was a medium effect size.

Table 2 shows the results of thermal check. For the Hiesho group, the average forehead temperature was $35.08^{\circ} \mathrm{C}$, which was higher than that in the non-Hiesho group $(p<0.01)$. On the contrary, non-Hiesho young females had a higher plantar temperature than those with Hiesho $\left(32.60\right.$ versus $\left.29.51^{\circ} \mathrm{C}\right)$. The $\Delta \mathrm{T}$ between the forehead and plantar showed significant difference between the two groups $\left(1.85^{\circ} \mathrm{C}\right.$ in the non-Hiesho group
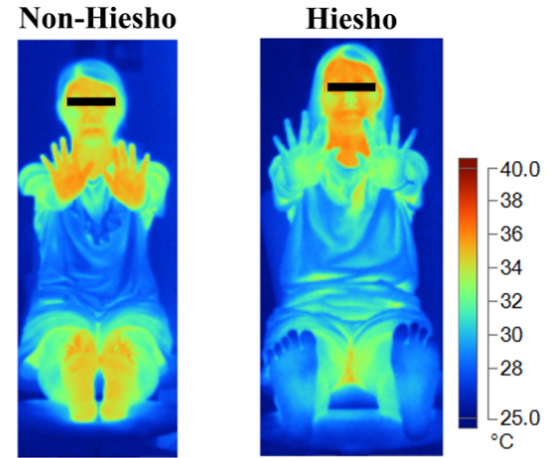

(a) sample of thermal check

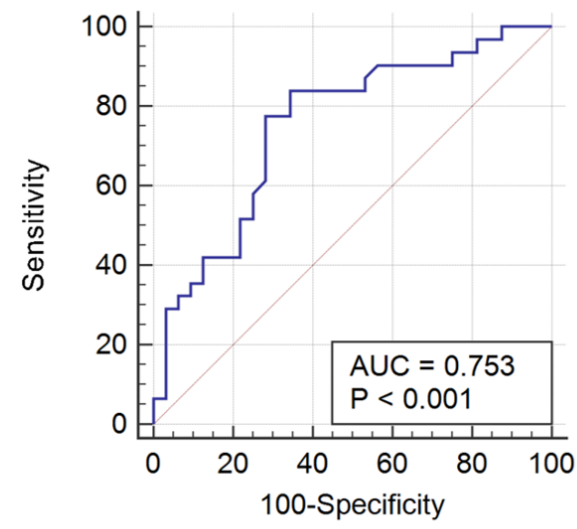

(b) ROC curve to define optimal $\Delta T$

Fig. 3 Example of thermal check and result of the ROC curve. (a) Samples of thermal check in two groups. The left thermal image is the non-Hiesho subject, and the right thermal image is a Hiesho subject. The color bar indicates the temperature range in the images. (b) Receiver operating characteristics curve to predict optimal $\Delta \mathrm{T}$ for defining Hiesho.

Table 1 Age and physical characteristics.

\begin{tabular}{ccccc}
\hline \hline & $\begin{array}{c}\text { non-Hiesho } \\
(N=32)\end{array}$ & $\begin{array}{c}\text { Hiesho } \\
(N=31)\end{array}$ & $p$ value & Cohen's $d$ \\
\hline $\begin{array}{c}\text { Age } \\
(\text { years })\end{array}$ & $21.1(1.8)$ & $22.0(1.5)$ & $<0.05$ & 0.524 \\
$\begin{array}{c}\text { Height } \\
(\mathrm{cm})\end{array}$ & $158.70(6.28)$ & $157.11(5.84)$ & 0.30 & -0.263 \\
$\begin{array}{c}\text { Weight } \\
(\mathrm{kg})\end{array}$ & $52.39(7.04)$ & $50.47(5.03)$ & 0.22 & -0.312 \\
$\begin{array}{c}\mathrm{BMI} \\
\left(\mathrm{kg} / \mathrm{m}^{2}\right)\end{array}$ & $20.75(2.01)$ & $20.48(2.08)$ & 0.60 & -0.133 \\
\hline \hline
\end{tabular}

Value: mean (standard deviation)

BMI: body mass index

versus $5.55^{\circ} \mathrm{C}$ in the Hiesho group, $\left.p<0.01\right)$. Cohen's $\mathrm{d}$ indicated that these were large effects.

Table 3 shows the results of physiological indicators. There were no significant differences between non- 
Table 2 Results of thermal check.

\begin{tabular}{lcccc}
\hline \hline & $\begin{array}{c}\text { non-Hiesho } \\
(N=32)\end{array}$ & $\begin{array}{c}\text { Hiesho } \\
(N=31)\end{array}$ & $p$ value & Cohen's $d$ \\
\hline FT $\left({ }^{\circ} \mathrm{C}\right)$ & $34.43(0.69)$ & $35.08(0.57)$ & $<0.01$ & 1.020 \\
$\mathrm{PT}\left({ }^{\circ} \mathrm{C}\right)$ & $32.60(1.20)$ & $29.51(1.36)$ & $<0.01$ & -2.403 \\
$\Delta \mathrm{T}\left({ }^{\circ} \mathrm{C}\right)$ & $1.85(1.23)$ & $5.55(1.40)$ & $<0.01$ & 2.854 \\
\hline \hline
\end{tabular}

Value: mean (standard deviation)

FT: forehead temperature

PT: plantar temperature

$\Delta \mathrm{T}$ : Temperature difference

Table 3 Results of physiological indicators.

\begin{tabular}{ccccc}
\hline \hline & $\begin{array}{c}\text { non-Hiesho } \\
(N=32)\end{array}$ & $\begin{array}{c}\text { Hiesho } \\
(N=31)\end{array}$ & $p$ value & Cohen's $d$ \\
\hline $\begin{array}{c}\mathrm{SBP} \\
(\mathrm{mmHg}) \\
\mathrm{DBP} \\
(\mathrm{mmHg}) \\
\mathrm{cSBP} \\
(\mathrm{mmHg})\end{array}$ & $68.5(7.2)$ & $69.0(6.0)$ & 0.96 & 0.012 \\
$\begin{array}{c}\mathrm{PP} \\
(\mathrm{mmHg})\end{array}$ & $32.8(5.5)$ & $32.4(6.3)$ & 0.78 & -0.070 \\
$\begin{array}{c}\mathrm{PR} \\
(\mathrm{BPM})\end{array}$ & $70.4(9.7)$ & $72.3(8.9)$ & 0.41 & 0.211 \\
$\begin{array}{c}\mathrm{AI} \\
(\%)\end{array}$ & $52.5(10.7)$ & $56.1(10.9)$ & 0.20 & 0.331 \\
\hline \hline
\end{tabular}

Value: mean (standard deviation)

SBP: systolic blood pressure

DBP: diastolic blood pressure

cSBP: central systolic blood pressure

PP: pulse pressure

PR: pulse rate

AI: augmentation index

Hiesho and Hiesho groups. However, there was a trend that Hiesho group had higher cSBP than non-Hiesho group $(100.1 \pm 7.0$ versus $98.9 \pm 8.4 \mathrm{mmHg})$. Hiesho group also showed a tendency of higher pulse rate (72.3 \pm 8.9 BPM) compared to non-Hiesho group (70.4 \pm 9.7 BPM). Higher AI in Hiesho group $(56.1 \pm 10.9 \%)$ indicated a trend of stiffer peripheral blood vessel than in non-Hiesho group $(52.5 \pm 10.7 \%)$.

\section{Discussion}

In this study, we defined Hiesho among young females based on a questionnaire. As a result, 31 in 63 people (49\%) were defined to have Hiesho. Previous studies also reported that approximately half of young women in
Japan suffered from Hiesho [16-18], similar to our finding. However, it has to be emphasized that body temperature in Hiesho patients varies in different seasons [19], and performing experiments in the same season is recommended. The age of Hiesho group was higher than that of non-Hiesho group (22 versus 21.1 years), even though the difference was less than one year. Most of the subjects aged 22 years were in their fourth year of university, and were facing job hunting and undergoing hospital training. Compared to more junior students, they may have had more mental stress, irregular diet, and lack of sleep, which were related to Hiesho [20].

The average skin temperature at the forehead in the Hiesho group $\left(35.08^{\circ} \mathrm{C}\right)$ was significantly higher than that in the non-Hiesho group $\left(34.43^{\circ} \mathrm{C}\right)$. A similar result was also found in a previous study [8], in which Nakamura observed that Hiesho patients had a higher core temperature at the forehead, resulting in higher skin temperature. During our experiment, the indoor temperature was set at approximately $25^{\circ} \mathrm{C}$. Under similar conditions, the forehead skin temperature of females ranged from 34 to $35^{\circ} \mathrm{C}$ [21]. However, owing to lower metabolism, heat production in the Hiesho group was lower than that in the non-Hiesho group [22]. The heat loss must be decreased to maintain a balance between heat production and heat loss to keep a constant core temperature. Accordingly, cutaneous vasoconstrictor reduced blood flow at the extremities, resulting in a low skin temperature but higher core temperature [23]. We considered that this was the reason why Hiesho patients felt cold in an environment where healthy subjects did not.

Nakamura [20] summarized two main factors that resulted in Hiesho. The first is internal factors such as sympathetic nerve, blood flow, female hormones, vasomotor nerve, and ying-yang balance. The second is external factors including mental stress, smoking, overworking, and sleep deprivation. The exact mechanism of Hiesho is still unclear, but some studies have indicated that Hiesho might be a heritable phenotype [1] and associated with hypersensitive to the surrounding environment $[24,25]$. Although Hiesho is not perceived as a remarkable symptom, a new concept that deals with cold feeling at extremities, called Flammer syndrome (FS), has been observed recently in Western medicine [6]. According to Flammer et al. [26], FS describes the phenotype of people with a predisposition for an altered reaction of the blood vessels to stimuli such as coldness, emotional stress, and hypoxia. Symptoms of patients with FS seem to be consistent with those of females with Hiesho in Japan. Similar to a statistical report [27], FS occurs more often in females than males in Europe [28, 29]. We acknowledged the significance of investigating the reasons for Hiesho both from the viewpoints of West- 
ern and Eastern medicine, but it was beyond the scope of this paper. More studies on the relation between Hiesho and Flammer syndrome are expected.

In this research, we proposed a quantitative method for defining Hiesho by the skin temperature difference between the forehead and the foot sole. After cross-checking with the result of a subjective questionnaire, our proposed method had a sensitivity of $77.4 \%$ and a specificity of $71.9 \%$. Meanwhile, measuring different temperatures using an infrared thermometer provided a non-invasive method to discriminate Hiesho rapidly and with acceptable accuracy. Recently, several researchers have sought to solve this health problem. A previous study proposed to measure the blood flow from the radial artery at the wrist of Hiesho patients by studying Doppler ultrasound peripheral vascular flow [30]. In this six-month followup study, the authors observed that blood flow could be an effective approach for monitoring personal health of Hiesho patients. However, the difference in blood flow between Hiesho patients and healthy subjects was not known because they did not perform control experiment and there were only four subjects in their study.

In this study, we measured blood pressure, pulse wave, and augmentation index to evaluate physiological indicators. Although there were no differences in systolic and diastolic blood pressures between non-Hiesho and Hiesho groups, central blood pressure showed a higher trend in subjects who had Hiesho. Previous studies also reported no difference in blood pressure between subjects with Hiesho and healthy subjects $[10,31]$. It was interesting to notice that pulse rates in both non-Hiesho and Hiesho groups in this study (72.3 BPM in Hiesho and 70.4 BPM in non-Hiesho) were higher than those in previous report (60 BPM in Hiesho and approximately $65 \mathrm{BPM}$ in non-Hiesho group) [10]. Meanwhile, it seemed that young females with Hiesho had higher heart rates. Ogata et al. [10] summarized that higher heart rate in Hiesho group was due to higher sympathetic nerve activity, which can be analyzed through heart rate variability (HRV). However, we did not perform HRV analysis in this study.

It has been shown that augmentation index is closely related to arterial stiffness, and a positive relationship between age and AI has also been reported [32]. We also observed a trend that AI was higher in Hiesho than in non-Hiesho group, and age was different between the two groups. Kohara et al. [33] reported that AI was approximately $65 \%$ in women aged from the $20 \mathrm{~s}$, which was higher than those of both Hiesho and healthy groups in our study ( $52.5 \%$ and $56.1 \%$ respectively). We speculated that because all subjects recruited in our study were in their early 20s, peripheral blood vessel was softer compared to the average.
There were several limitations in this study. According to an epidemiological survey [34], the percentage of women who self-reported Hiesho increased from 30\% (under 40 years) to $50 \%$ (50 years or older). Hiesho seems to be an age-related health problem. However, only young females in their early twenties were recruited for this research. As physical and psychological conditions change continuously with age for females, examining more subjects across different age groups would be necessary in future study. Meanwhile, as it has been reported that $67 \%$ of pregnant women have Hiesho [8] and that Hiesho might be a heritable phenotype [1], a follow-up study on this topic could provide more information on Hiesho and its pathogeny.

In this study, all subjects were Japanese. Hiesho is also known in other countries [1-3]. Due to the differences in habits and living conditions, the reason of Hiesho may be different. Thus it is difficult to generalize the findings of this research. Meanwhile, 153 men out of 10,000 from the general population in Japan were reported to have Hiesho [27]. As such, Hiesho affects both genders. We did not recruit male subjects in this study.

\section{Conclusion}

In this paper, we proposed an objective and quantitative approach to define Hiesho. Thermal check results indicate that young females with Hiesho have considerable temperature difference between the forehead and the foot sole. A difference in temperature of $3.64^{\circ} \mathrm{C}$ between the forehead and the foot sole can be utilized as the threshold for distinguishing Hiesho.

\section{Competing Interests}

The authors declare no competing financial interests.

\section{Acknowledgement}

The authors wish to acknowledge the support from KASHIYAMA Scholarship Foundation (F18241).

The authors wish to thank all reviewers for their comments to improve this paper.

\section{References}

1. Hur YM, Chae JH, Chung KW, Kim JJ, Jeong HU, Kim JW, Seo SY, Kim KS: Feeling of cold hands and feet is a highly heritable phenotype. Twin Res Hum Genet. 15(2), 166-169, 2012.

2. Park KS, Park KI, Kim JW, Yun YJ, Kim SH, Lee CH, Park JW, Lee JM: Efficacy and safety of Korean red ginseng for cold hypersensitivity in the hands and feet: A randomized, double-blind, placebo-controlled trial. J Ethnopharmacol. 158, 25-32, 2014.

3. Wang T, Endo M, Uehara H, Suga S, Matsuzaki M, Nakamoto G, Ohno Y: Plantar tactile sensation for young females with Hiesho. Proc of 2020 IEEE 2nd Global Conference on Life Sciences and Technologies, Kyoto, Japan, pp. 329-330, 2020.

4. Mori H, Kuge H, Sakaguchi S, Tanaka TH, Miyazaki J: Determi- 
nation of symptoms associated with hiesho among young females using hie rating surveys. J Integr Med. 16(1), 34-38, 2018.

5. Bae KH, Go HY, Park KH, Ahn I, Yoon Y, Lee S: The association between cold hypersensitivity in the hands and feet and chronic disease: results of a multicentre study. BMC Complement Altern Med. 18(1), 1-8, 2018.

6. Tsuboi S, Mine T, Tomioka Y, Sshiraishi S, Fukushima F, Ikaga T: Are cold extremities an issue in women's health? Epidemiological evaluation of cold extremities among Japanese women. Int J Womens Health. 11, 31-39, 2019.

7. Hottenbacher L, Weißhuhn TER, Watanabe K, Seki T, Ostermann J, Witt CM: Opinions on Kampo and reasons for using it results from a cross-sectional survey in three Japanese clinics. BMC Complement Altern Med. 13, 108, 2013.

8. Nakamura S: Sensitivity to cold in pregnant women: characteristics of skin temperature and its relationship to daily Life [in Japanese]. J Japan Acad Nurs Sci. 28(1), 3-11, 2008.

9. Sakaguchi S, Kuge H, Mori H, Miyazaki J, Tanaka TH, Hanyu K, Takeda T, Sasaki K: Extraction of items identifying hiesho (cold disorder) and their utility in young males and females. J Integr Med. 14(1), 36-43, 2016.

10. Ogata Y, Kaneko K, Goto K, Kono K, Yamamoto M: Physiological mechanism of Hiesho: evaluation by cardiovascular and autonomic dynamics [in Japanese]. Japanese J Nurs Art Sci. 15(3), 227-234, 2017.

11. Iriki M: From the viewpoint of Maintain and Adjust Homeostasis. In: Iriki M ed. Let's get started!!: body temperature physiology, Tokyo: Kunkodo, pp. 200-208. 2003.

12. Japan Weather Association. Osaka Weather. <https://tenki.jp/ past/2019/07/weather/6/30/47772/> [data accessed 2020 Jun 5].

13. Fluke Corporation. Fluke Ti405 Thermal Camera. <https:// www.fluke.com/ja-jp/product/thermal-cameras/ti450 \#country-picker-mobile> [data accessed 2020 Jun 24].

14. Wang T, Jeong H, Okada S, Ohno Y: Noninvasive measurement for emotional arousal during acupuncture using thermal image. Proc of 2019 IEEE 1st Global Conference on Life Sciences and Technologies, Osaka, Japan, pp. 63-64, 2019.

15. Takase H, Dohi Y, Kimura G: Distribution of central blood pressure values estimated by Omron HEM-9000AI in the Japanese general population. Hypertens Res. 36(1),50-57, 2013.

16. Miura T, Katano Y, Sumimoto K, Kanayama N: Awareness of hiesho among adult women and research into its causes. Maternal Health. 4, 784-789, 2001.

17. Sakaguchi S: Concerning Hiesho. Biomedical Thermology. 21, 60-63, 2001.

18. Miyazaki J, Guge H, Morisawa T, Sakaguchi S, Takada T, Sasaki $\mathrm{K}$, Mori $\mathrm{H}$ : Behaviour factor in Hiesho (excessive sensitivity to cold symptoms), health-related QOL and BMI in male and female subjects who feel Hiesho [in Japanese]. Zen Nihon Shinkyu Gakkai Zasshi (Journal Japan Soc Acupunct Moxibustion). 61(2), 174-181, 2011.

19. Komoda N, Fuzikawa A, Mori H, Kuge H, Ueda S, Sakaguchi S, Kazushi N: Stress thermography for excessive sensitivity to cold: seasonal difference in postural change tests [in Japanese]. Biomed Thermol. 27(2), 67-70, 2008.

20. Nakamura S: "Sensitivity to cold": a concept analysis [in Japanese]. J Japan Acad Nurs Sci. 30(1), 62-71, 2010.
21. Iriki M: Body temperature. In: Iriki $\mathbf{M}$ ed. Let's get started!!: body temperature physiology, Tokyo: Kunkodo, pp. 8, 2003.

22. Kusumi Y, Emori Y: Evaluation of hiesho using a cold-water load test in adult females [in Japanese]. J Japan Acad Midwifery. 23(2), 241-250, 2009.

23. Kanosue K, Nagashima K, Taniguchi A, Konishi M: What is thermal comfort/discomfort (hotness/coldness) [in Japanese]. J Japan Res Assoc Text End-Uses. 43(3), 159-164, 2020.

24. Yamazaki F: The cutaneous vasoconstrictor response in lower extremities during whole-body and local skin cooling in young women with a cold constitution. J Physiol Sci. 65(5), 397-405, 2015.

25. Yamazaki F, Fujita M, Watanabe Y: The thermal sensation and cutaneous vasomotor response to local thermal load in winter and summer seasons in young women with a cold constitution [in Japanese]. Acad Arch Yamaguchi Prefect Univ Bull Rec Res Act. 11, 1-9, 2018.

26. Flammer J, Konieczka K: The discovery of the Flammer syndrome: A historical and personal perspective. EPMA J. 8(2), 75-97, 2017.

27. Japanese Ministry of Health, Labour and Welfare. The 9th National Livelihood Survey 2013. <https://www.mhlw.go.jp/ toukei/saikin/hw/k-tyosa/k-tyosa10/> [data accessed 2020 Jun $10]$.

28. Weller RB: Sunlight has cardiovascular benefits independently of vitamin D. Blood Purif. 41(1-3), 130-134, 2016.

29. Konieczka K, Erb C: Diseases potentially related to Flammer syndrome. EPMA J. 8, 327-332, 2017.

30. Takeuchi H, Kodama N: Doppler ultrasound peripheral vascular flow study as a means of personal healthcare. Takasaki Univ Health Welfare Rep. 15, 1-9, 2016.

31. Yamazaki F, Liyama H, Iwata K, Kato M: Electroencephalogram characteristics during local and whole-body skin cooling in women with a cold constitution. Jpn J Miometeor. 56(1), 25-33, 2019.

32. Weber T, Auer J, O'Rourke MF, Kvas E, Lassnig E, Berent R, Eber B: Arterial stiffness, wave reflections, and the risk of coronary artery disease. Circulation. 109(2), 184-189, 2004.

33. Kohara K, Tabara Y, Oshiumi A, Miyawaki Y, Kobayashi T, Miki T: Radial augmentation index: A useful and easily obtainable parameter for vascular aging. Am J Hypertens. 18(S1), 11s-14s, 2005.

34. Ushiroyama T, Kajimoto Y, Sakuma K, Ueki M: Assessment of chilly sensation in Japanese women with laser doppler fluxmetry and acceleration plethysmogram with respect to peripheral circulation. Bull Osaka Med Coll. 51(2), 76-84, 2005. 


\section{Tianyi WANG}

Tianyi WANG received his Ph.D. Degree in Health Science from Osaka University, Japan in 2020. For present, he is a senior researcher in Department of Robotics, Faculty of Science and Engineering, Ritsumeikan University. His research interests include engineering in healthcare science, human-

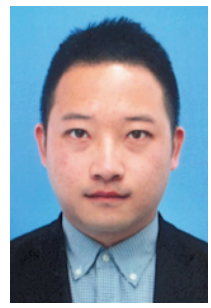
robot interaction, human posture and application of artificial intelligence for healthcare robot. Affiliated academic society: IEEE Life Science Community, IEEE Young Professionals, The Society for Nursing Science and Engineering, Japan Society of Maternal Health.

\section{Shima ОKaDA}

Shima ОкаDA completed the doctoral program at the Graduate School of Medicine, Osaka University in 2009 (Doctor of Health Science). She is an Associate Professor in Ritsumeikan University, Department of Robotics, Faculty of Science and Engineering where she has been a faculty member

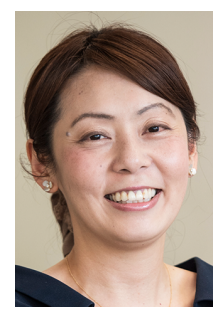
since 2017. She has collaborated actively with researchers in several other disciplines of biomedical engineering, particularly bio signal sensing at the hardware/software interface. Affiliated academic societies: IEEE Engineering in Medicine and Biology Society, Japan Society for Kansei Engineering, Japan Society for Biomedical Engineering.

\section{Masayuki Endo}

Masayuki ENDO earned his medical degree from Osaka University and his Ph.D from division of gene therapy science at Osaka University. He spent 4 years as a post-doctoral Research fellow at Center for Fetal Research in The Children's Hospital of Philadelphia (CHOP) studying Fetal Stem cell and

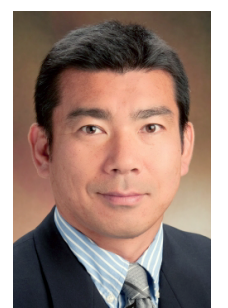
Gene Therapy and one year at University of Leuven in Belgium studying Urogynecology. He also served a two-years clinical fellow in the Center for Fetal Diagnosis and Treatment at CHOP. He is a professor of Department of Children's and Women's Health, Graduate School of Medicine, Division of Health Science, Osaka University and an associate professor of Division of Obstetrics and Gynecology at Osaka University. His area of interests includes fetal stem cell and gene therapy in fetal medicine and vaginal mechanical function during pregnancy in urogynecology. He is a member of Japan Fetal Group and propels development of Fetal Diagnosis and Treatment in Japan.

\section{Masaaki MaKIKAWA}

Masaaki MakiKaWA received his $\mathrm{PhD}$ degree from Osaka University in 1985. He was an assistant professor at the Department of Orthopedic Surgery, Shiga University of Medical Sciences in 19821986, a research fellow of the Research Institute of the National Cardiovascular Center in 1986-1990,

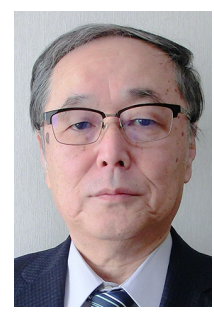
an associate professor at the Department of Biophysical Engineering in 1990-1996, and a professor at the Department of Robotics, College of Science and Engineering at Ritsumeikan University in 1996-2017. He is a Professor Emeritus and a Specially Appointed Professor of Ritsumeikan University, and Executive Assistant of Ritsumeikan Trust. He was an Editor-in-chief of JSMBE in 2009-2012. His research interests include biosignal instrumentation, biomechanics, and bioinformatics. He is member of the IEEE, the JSMBE, the SICE and the SOBIM.

\section{Yuko ОнNо}

Yuko OнNo received the Ph.D. degree in Institute of Medical Engineering from University of Tokyo, Japan, in 1985. She successively worked as a research fellow in National Institute of Statistical Mathematics, Research Institute of National Cancer Center, and Tokyo Metropolitan Institute for

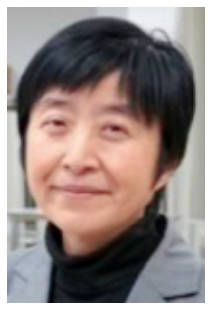
Neuroscience. Since 1995, she has been a professor in Osaka University Graduate School of Medicine, Suita, Japan. Her research interests include Mathematical Health Science, Operation Metrics in Medical and Nursing service, Statistical analysis on the related Problem of Cancer Patients, Operation's Research in Medicine, Robotics \& Design for Innovative Healthcare. Now she belongs to the following societies; the IEEE, The Japanese Society of Public Health, the Operations Research Society of Japan, the Japanese Society for Wellbeing Science and Assistive Technology, Japanese Society for Medical and Biological Engineering, etc. 